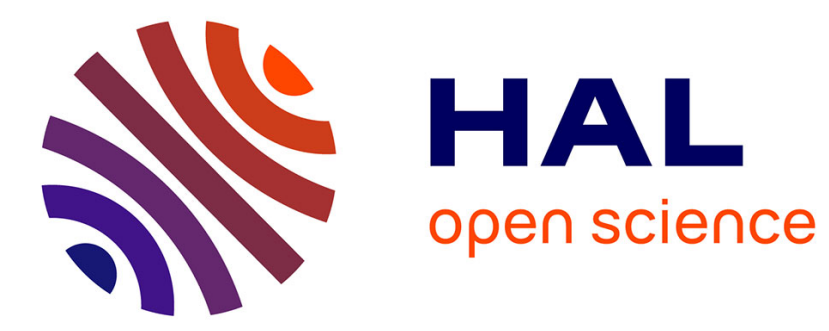

\title{
Improvement of the NOx selectivity for a planar YSZ sensor
}

Jing Gao, Jean-Paul Viricelle, Christophe Pijolat, Philippe Breuil, Philippe Vernoux, Antoinette Boreave, Anne Giroir-Fendler

\section{- To cite this version:}

Jing Gao, Jean-Paul Viricelle, Christophe Pijolat, Philippe Breuil, Philippe Vernoux, et al.. Improvement of the NOx selectivity for a planar YSZ sensor. Sensors and Actuators B: Chemical, 2011, 154 (2), pp.106-110. 10.1016/j.snb.2010.01.033 . hal-00590817

\section{HAL Id: hal-00590817 https://hal.science/hal-00590817}

Submitted on 5 May 2011

HAL is a multi-disciplinary open access archive for the deposit and dissemination of scientific research documents, whether they are published or not. The documents may come from teaching and research institutions in France or abroad, or from public or private research centers.
L'archive ouverte pluridisciplinaire HAL, est destinée au dépôt et à la diffusion de documents scientifiques de niveau recherche, publiés ou non, émanant des établissements d'enseignement et de recherche français ou étrangers, des laboratoires publics ou privés. 


\title{
Improvement of the NOx selectivity for a planar YSZ sensor
}

\author{
J ing Gao(1) , J ean-Paul Viricelle ${ }^{(1) *}$, Christophe Pij Olat ${ }^{(1)}$, PhilipPe Breuil(1), \\ PHILIPPE VERNOUX (2), ANTOINETTE BOREAVE(2), ANNE GIROIR-FENDLER ${ }^{(2)}$ \\ (1) Ecole Nationale Supérieure des Mines de Saint Etienne, Centre SPIN ; Département \\ MICC ; LPMG -UMR CNRS 5148, 158 Cours Fauriel - 42023 Saint-Étienne Cedex 2, \\ France \\ (2) IRCELYON, Université Lyon 1, CNRS, UMR 5256, 2 Avenue Albert Einstein, \\ 69626Villeurbanne Cedex, France
}

\begin{abstract}
In recent years planar yttria-stabilized zirconia (YSZ) based electrochemical gas sensors for automotive exhaust applications have become a major source of interest. The present work aims to develop a sensor for industrialisation. For this reason planar YSZ-based electrochemical sensors using two metallic electrodes (platinum and gold) were fabricated using screen-printing technology and tested in a laboratory test bench for different concentrations of pollutant gas such as $\mathrm{CO}, \mathrm{NO}, \mathrm{NO}_{2}$ and hydrocarbons in oxygen rich atmosphere. It was furthermore shown that the selectivity towards $\mathrm{NO}_{\mathrm{x}}$ could be highly reinforced by deposing a catalytic filter consisting of 1.7-4.5 wt.\% Pt dispersed on alumina directly on the sensing elements. This filter was characterized by the use of SEM, TPD and XRD.
\end{abstract}

Keywords:

Electrochemical gas sensor; NOx sensor; Catalytic filter; NOx selectivity; Automotive exhaust

\section{Introduction}

Since many years researchers have been working on the development of a reliable electrochemical gas sensor for automotive exhausts application to control the emission of carbon monoxide $(\mathrm{CO})$, nitrogen oxides $\left(\mathrm{NO}_{\mathrm{x}}\right)$, especially nitrogen monoxide (NO) and nitrogen dioxide $\left(\mathrm{NO}_{2}\right)$, and hydrocarbons $\left(\mathrm{CH}_{\mathrm{x}}\right)$. Potentiometric gas sensors with a solid electrolyte based on zirconia stabilized by yttria or scandia, YSZ or SSZ, respectively, or on $\beta$ alumina are considered as the most successful ones [1], [2], [3], and [4]. The sensing principle of this sensor type is based on the development of a mixed-potential as studied by many research groups [5], [6], and [7]. Furthermore a model of the detection mechanism has proposed by our group which explains the responses to oxygen [8] and hydrocarbons [9]. However, one of the major problems accounted with these sensors, as for other types, is the selectivity [10] and [11]. As the European Commission has focused in their latest emission requirements proposals (Euro V and Euro VI) specifically on the reduction of the $\mathrm{NO}_{\mathrm{x}}$ emission, one of the major challenges today is the enhancement of the $\mathrm{NO}_{\mathrm{x}}$ selectivity [12], [13], [14] and [15].

In order to meet this requirement, many approaches have been made. For instance, Miura et al. have proposed a complex impedance-based YSZ sensor using $\mathrm{ZnCr}_{2} \mathrm{O}_{4}$ sensing electrode to reduce inferring signals from other combustible gases and oxygen deviation disturbance [16]. In the potentiometric mode selectivity towards a gas species can be modified by changing the

\footnotetext{
* Auteur à qui la correspondance devait être adressée : viricelle@emse.fr
} 
sensing electrode. A good overview of electrode materials tested in the past was given in the review of Fergus [17]. Otherwise, it is possible to enhance the $\mathrm{NO}_{\mathrm{x}}$ selectivity by using an oxidation-catalyst electrode to oxide interferences and hence decrease cross-sensitivity from reducing gases [17]. The same effect can be reached if a catalyst is deposited before the gas mixture arrives to the sensing elements [18] and [19]. In the present work, it was opted to develop a planar potentiometric YSZ sensor with a catalytic filter directly deposited on the sensitive part of the sensor in order to meet the industrial demand of a robust, reliable $\mathrm{NO}_{\mathrm{x}}$ sensor with a simple configuration.

\section{Experimental}

For the fabrication of planar potentiometric sensors, screen-printing technology was used to deposit an YSZ solid electrolyte and two metallic electrodes (commercial pastes), one in gold and one in platinum, on an alumina sheet (Figure 1). Gold paste was equally used to establish the connection between the sensor and the acquisition system. On the back a platinum heating element is printed to ensure the control of the temperature.
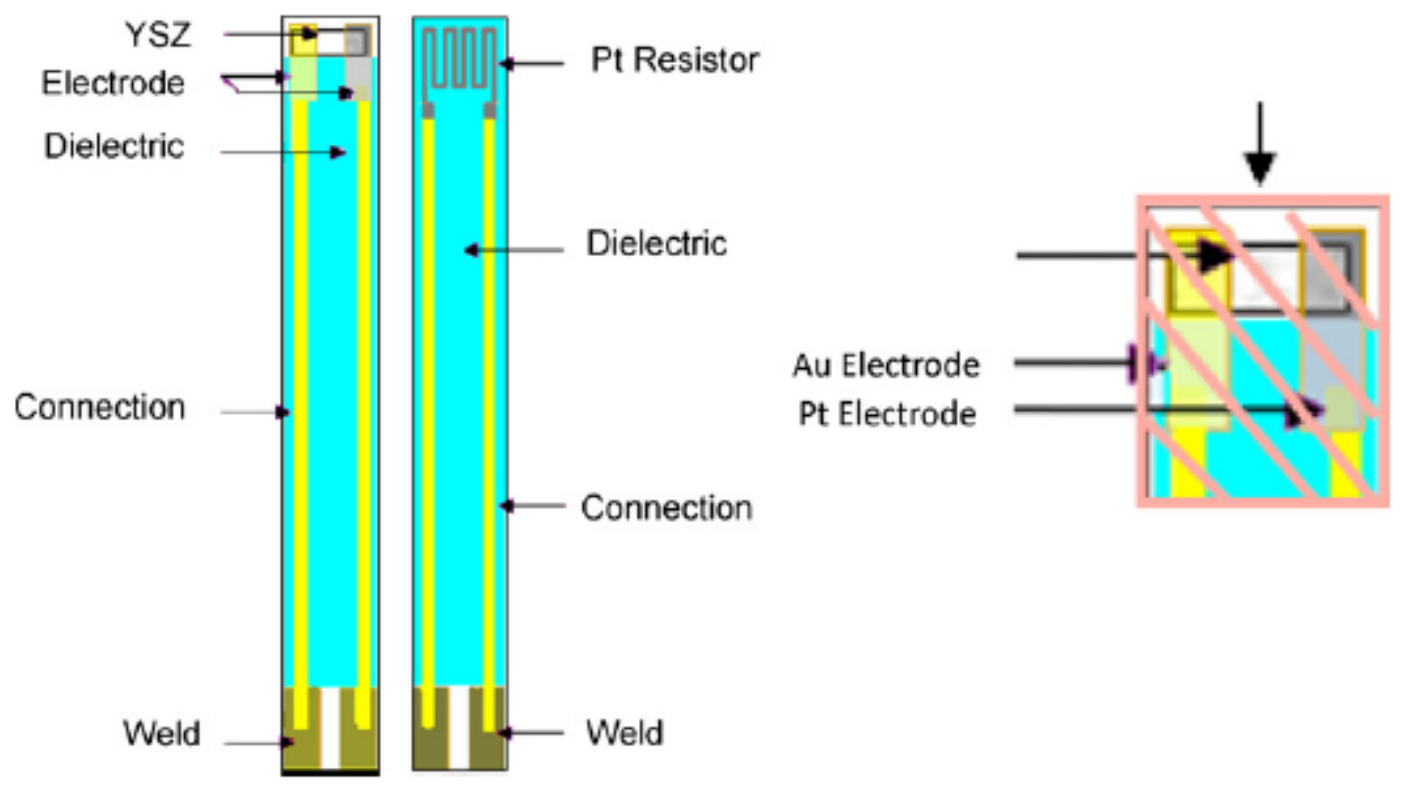

Figure 1: Schematic of the sensor.

In order to produce sensors with enhanced selectivity towards $\mathrm{NO}_{\mathrm{x}}$ a catalytic filter layer (40$80 \mu \mathrm{m}$ ) was deposited over the sensing elements with a subsequent calcination process at $850^{\circ} \mathrm{C}$ for an hour. After series of tests, two catalytic filters consisting of $1.7 \mathrm{wt} . \%$ and 4.5 wt.\% platinum dispersed in alumina (referred as Pt1.7 and Pt.4.5, respectively, in the following), were retained for further investigation.

The fabricated sensors were tested in a conventional flow apparatus (Figure 2). The gas flow in the sensing chamber consisted basically of a synthetic gas containing 12 vol.\% $\mathrm{O}_{2}$, 2 vol.\% $\mathrm{H}_{2} \mathrm{O}$ and nitrogen balance. Pollutant gases such as $\mathrm{CO}$, NO and $\mathrm{NO}_{2}$ were added to the base gas in a concentration range of $50-300 \mathrm{ppm}$. The total flow rate amounted to $30 \mathrm{l} / \mathrm{h}$. While the entering gas mixture had ambient temperature, the sensors were heated to $400-550{ }^{\circ} \mathrm{C}$ in order to establish an optimal working temperature. The measured electromotive force (denoted as EMF) was the potential difference between the gold and the platinum electrode $\left(\mathrm{V}_{\mathrm{Pt}}-\mathrm{V}_{\mathrm{Au}}\right)$. 


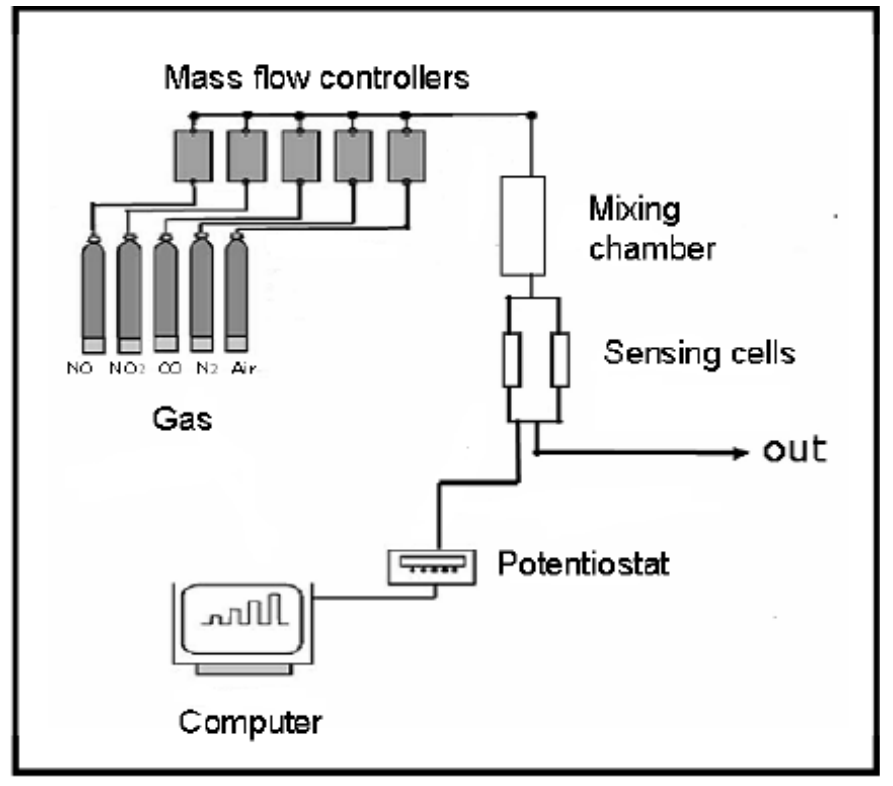

Figure 2: Test bench.

By applying X-ray diffraction (D-500o, Siemens) and scanning electron microscopy (Hitachi S-800) technologies the crystallographic structure and the surface morphology of the deposited catalytic filter layer were characterized.

The adsorption-desorption behaviour of $\mathrm{NO}_{2}$ was investigated by means of TPD. In a Ushaped quartz tube, $0.1 \mathrm{~g}$ of the Pt1.7 powder, used to fabricate the catalytic layer, was placed and heated to $450^{\circ} \mathrm{C}$. The sample was then exposed to a gas mixture consisting of $300 \mathrm{ppm}$ $\mathrm{NO}_{2}, 3.5 \%$ oxygen and helium balance for $12 \mathrm{~h}$ successively. The sample was then cooled down to room temperature in the same atmosphere and treated $10 \mathrm{~min}$ with pure helium. For the desorption, the sample was heated under helium up to $700{ }^{\circ} \mathrm{C}$ with a heating rate of $15{ }^{\circ} \mathrm{C} / \mathrm{min}$ and a helium flow rate of $3 \mathrm{l} / \mathrm{h}$. The $\mathrm{NO}, \mathrm{O}_{2}$ desorption were followed by a mass spectrometer (VGgas Smart-IQ ${ }^{+}$.

Furthermore, in order to determine the minimum temperature which is necessary to oxidize light hydrocarbons, a catalytic flow experiment has been carried out. $0.2 \mathrm{~g}$ of Pt 4.5 was introduced in a U-shaped quartz reactor. At a flow rate of $10 \mathrm{l} / \mathrm{h}$, the conversions into $\mathrm{CO}_{2}$ and $\mathrm{H}_{2} \mathrm{O}$ of various hydrocarbons (methane, propane and propene), either pure or mixed together, were determined by analysing the gas mixture with a microgas chromatograph (Varian, CP2003) and a near infrared spectrometer (EMERSON).

\section{Results and discussion}

\section{III.1. Sensing characteristics of the sensor without a catalytic layer}

In the absence of a catalytic filter layer and at $450{ }^{\circ} \mathrm{C}$ (temperature at which the sensitivity to $\mathrm{NO}_{\mathrm{x}}$ reached its maximum), a positive response in regard to the baseline recorded in $12 \%$ oxygen with nitrogen balance was obtained for reducing gases such as $\mathrm{CO}$ and NO (Figure 3), whereas the oxidizing gas $\mathrm{NO}_{2}$ responded negatively. This was due to the difference in the redox potential of the gases and the different electrocatalytic properties of the electrodes. Similar sensing behaviour has been reported already in the literature [20]. Remarkable is the fact that $\mathrm{NO}_{2}$ has a much higher sensitivity than NO.

\section{III.2. XRD and SEM characterisation of the filter layer}

In order to characterize the deposited catalytic filter layer Pt1.7 X-ray diffraction analysis (XRD) and scanning electron microscopy (SEM) were used. By applying XRD technology only alumina ( $\alpha$ - and $\gamma$-phase) and platinum crystallographic phases were detected which indicated that there was no major pollution on the catalytic layer.

SEM pictures of secondary electrons and backscattered electrons (Figure 4) showed that the surface of the catalytic layer was non-fissured. The image of backscattered electrons revealed 
that the platinum particles are not totally homogeneously dispersed on the surface of the support with alumina areas of about $5 \mu \mathrm{m}^{2}$ not covered with platinum. This is probably due to the calcination step during the deposition process which leads to Pt particles sintering.

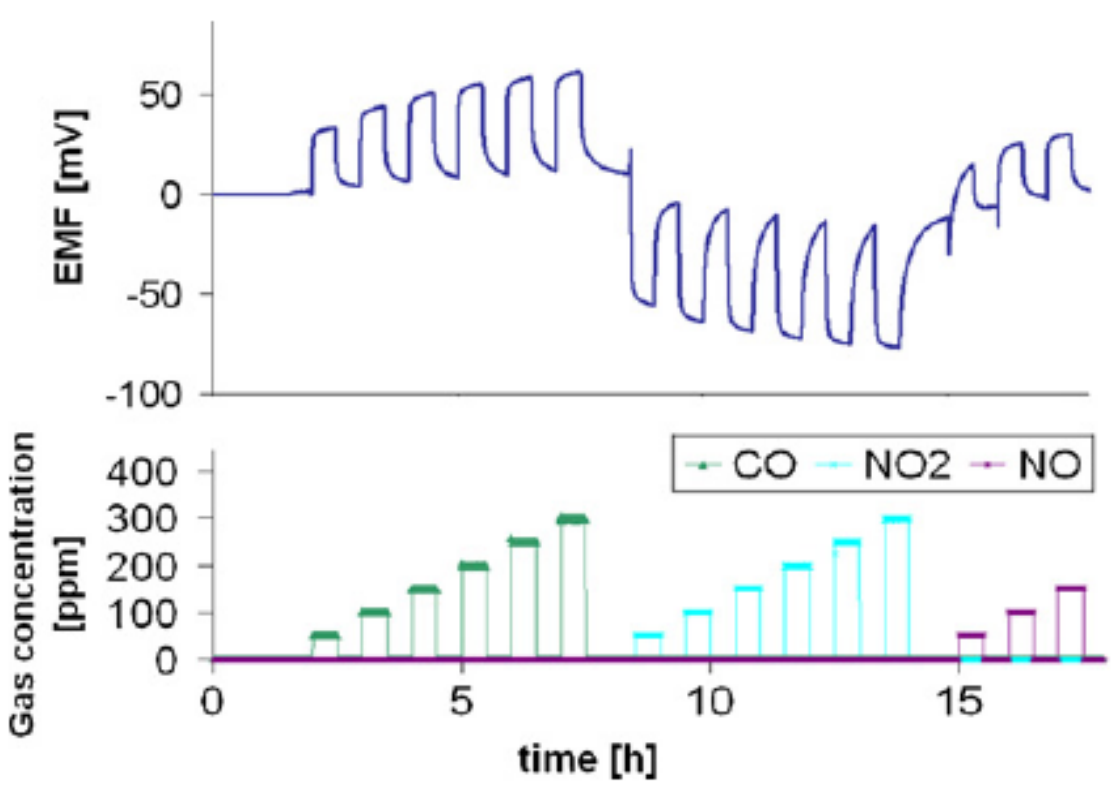

Figure 3: Sensor response to $\mathrm{CO}, \mathrm{NO}$ and $\mathrm{NO}_{2}$ at $450{ }^{\circ} \mathrm{C}$ (base gas: 12 vol. $\% \mathrm{O}_{2}, 2$ vol.\% $\mathrm{H}_{2} \mathrm{O}$ and $\mathrm{N}_{2}$ balance).
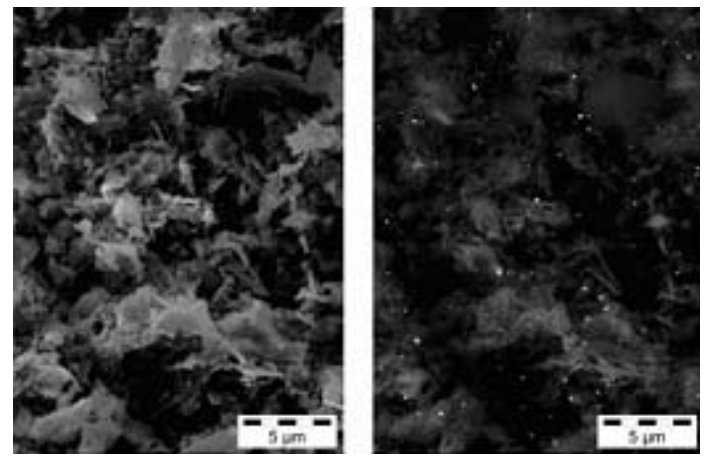

Figure 4: SEM of a deposed catalytic layer (Pt1.7=1.7\% Pt dispersed in alumina); left: secondary electron image; right: backscattering electron image.

\section{III.3. Sensing characteristics of the sensor with a Pt/alumina catalytic layer}

As it is seen in Figure 3, the strong sensor response to $\mathrm{CO}$ would significantly influence the $\mathrm{NO}_{\mathrm{x}}$ signal if not eliminated. By deposing a catalytic layer consisting of Pt1.7 the sensor response to $\mathrm{CO}$ can be suppressed at a temperature above $300{ }^{\circ} \mathrm{C}$ as the catalytic properties of the Pt/alumina layer are sufficient to fully oxidize $\mathrm{CO}$ to the non-reactive gas $\mathrm{CO}_{2}$. Measurements presented in Figure 5 were shifted from the optimum temperature of $450{ }^{\circ} \mathrm{C}$ as mentioned in Section III.1. to $520 \mathrm{C}$ with a loss of sensibility of approximately $5 \mathrm{mV}$. This temperature increase was necessary to avoid a deactivation of the platinum, as discussed in the next paragraph.

If furthermore both $\mathrm{NO}$ and $\mathrm{NO}_{2}$ were considered, it is necessary to avoid a cancelling out of the overall sensing response to $\mathrm{NO}_{\mathrm{x}}$, as $\mathrm{NO}$ and $\mathrm{NO}_{2}$ lead to opposite signals. Therefore it is preferable to obtain a $\mathrm{NO} / \mathrm{NO}_{2}$ ratio which is only dependent on the working temperature. Platinum is said to be an efficient catalyst to catalyse $\mathrm{NO}$ and $\mathrm{NO}_{2}$ to the thermodynamic equilibrium. Therefore, independently on the $\mathrm{NO} / \mathrm{NO}_{2}$ ratio arriving at the sensor, a ratio according to the thermodynamic equilibrium is achieved by passing through the catalytic filter and the same response should be obtained proportional to the overall $\mathrm{NO}_{\mathrm{x}}$ concentration. This theory is in very good agreement with our experimental results as a 
response with a similar magnitude of approximately $20 \mathrm{mV}$ was obtained for an injection of $200 \mathrm{ppm}$ of $\mathrm{NO}$ or $\mathrm{NO}_{2}$ at $520{ }^{\circ} \mathrm{C}$. According to the thermodynamical equilibrium the ratio of $\mathrm{NO} / \mathrm{NO}_{2}$ should be close to 1 at this temperature. Therefore, as the sensor is more sensitive to $\mathrm{NO}_{2}$ than to NO, the sensor signal was negative (Figure 5).

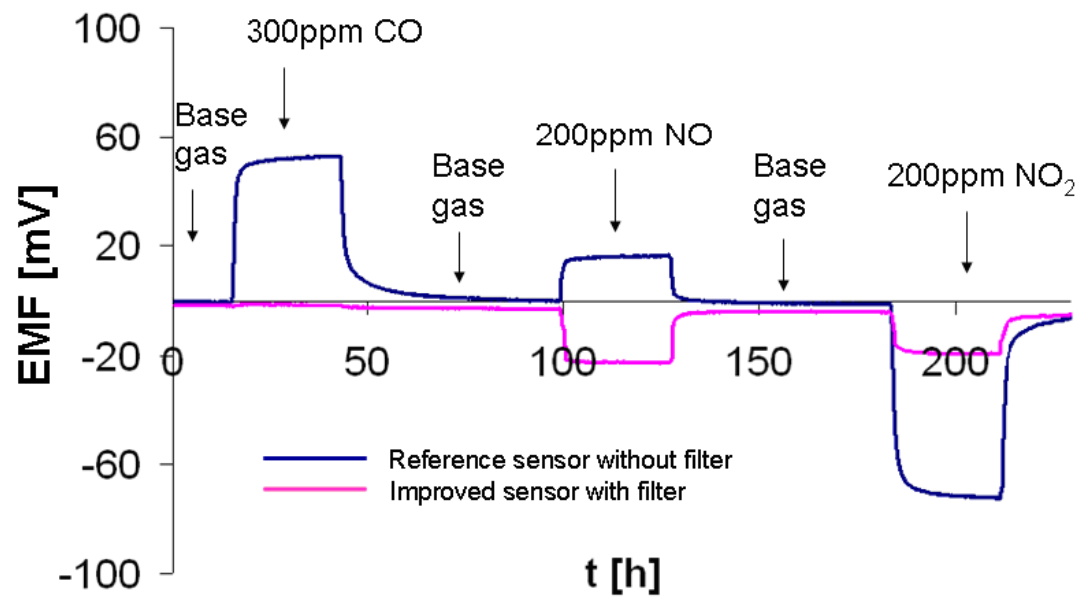

Figure 5: Response of a sensor with a catalytic layer (Pt1.7 $=1.7 \%$ Pt dispersed in alumina) to $\mathrm{CO}, \mathrm{NO}$ and $\mathrm{NO}_{2}$ at $520{ }^{\circ} \mathrm{C}$ in the presence of $12 \mathrm{vol} . \% \mathrm{O}_{2}, 2$ vol. $\% \mathrm{H}_{2} \mathrm{O}$ and $\mathrm{N}_{2}$ balance.

\section{III.4. Deactivation and regeneration of the catalytic filter layer}

Figure 6 shows a typical progression of the deactivation of the sensor response at $450{ }^{\circ} \mathrm{C}$. At the beginning of the experiment, a full oxidation of $\mathrm{CO}$ was achieved, therefore no response to $\mathrm{CO}$ was observed. After $2 \mathrm{~h}$ of permanent exposure to a gas mixture containing $200 \mathrm{ppm}$ of $\mathrm{NO}_{2}$ in $12 \%$ oxygen, the catalytic performance of the filter dropped. CO could not be any longer totally converted to $\mathrm{CO}_{2}$ and a small response of the order of $+10 \mathrm{mV}$ to $\mathrm{CO}$ was observed. This response became more important, reaching $+15 \mathrm{mV}$ if the sensor was further exposed to $\mathrm{NO}_{2}$ for $3 \mathrm{~h}$.

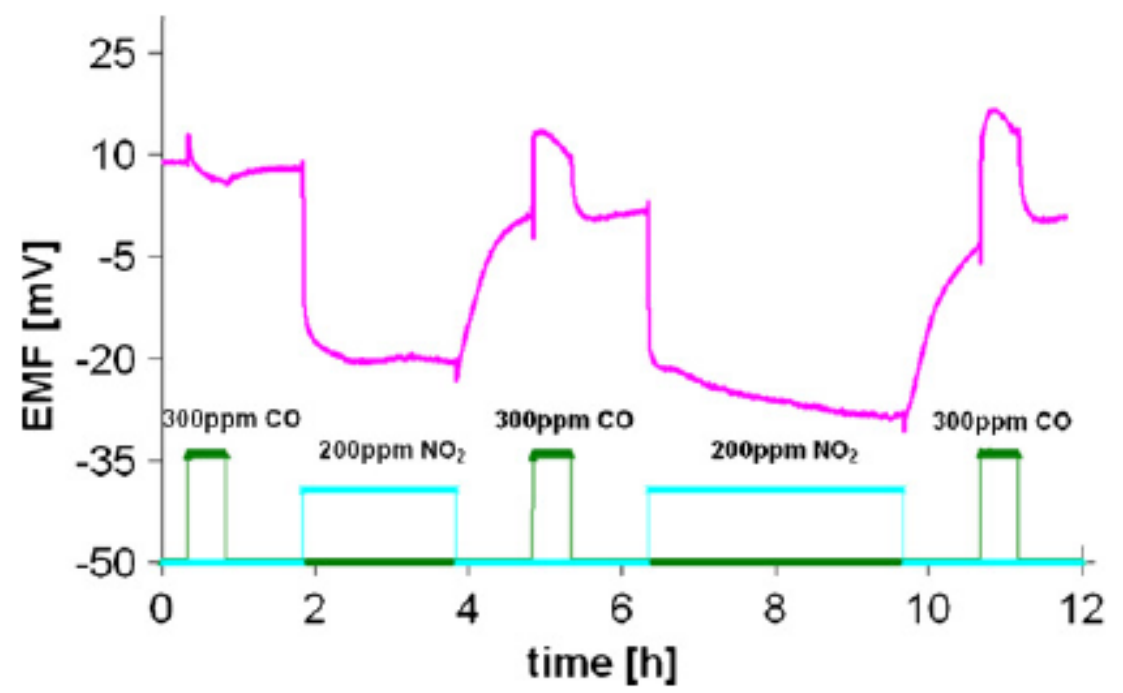

Figure 6: Deactivation process of the catalytic layer (Pt1.7 $=1.7 \%$ Pt dispersed in alumina) at $450{ }^{\circ} \mathrm{C}$ in the presence of $12 \mathrm{vol} . \% \mathrm{O}_{2}, 2 \mathrm{vol} . \% \mathrm{H}_{2} \mathrm{O}$ and $\mathrm{N}_{2}$ balance.

However, this kind of deactivation is reversible. It was found that a deactivated sensor could be regenerated by a calcination procedure. Figure 7 shows a sensor with a deactivated filter which responded to $300 \mathrm{ppm} \mathrm{CO}$ at the beginning of the test (EMF of about $+10 \mathrm{mV}$ ). The sensor was then heated at $700{ }^{\circ} \mathrm{C}$ for $1 \mathrm{~h}$ before it was cooled down back to $450^{\circ} \mathrm{C}$. The baseline response shifted to a higher background value, but when the sensor was exposed 
again to $\mathrm{CO}$ (300 ppm in air), no response was observed, suggesting that the catalytic properties of the filter were reactivated.

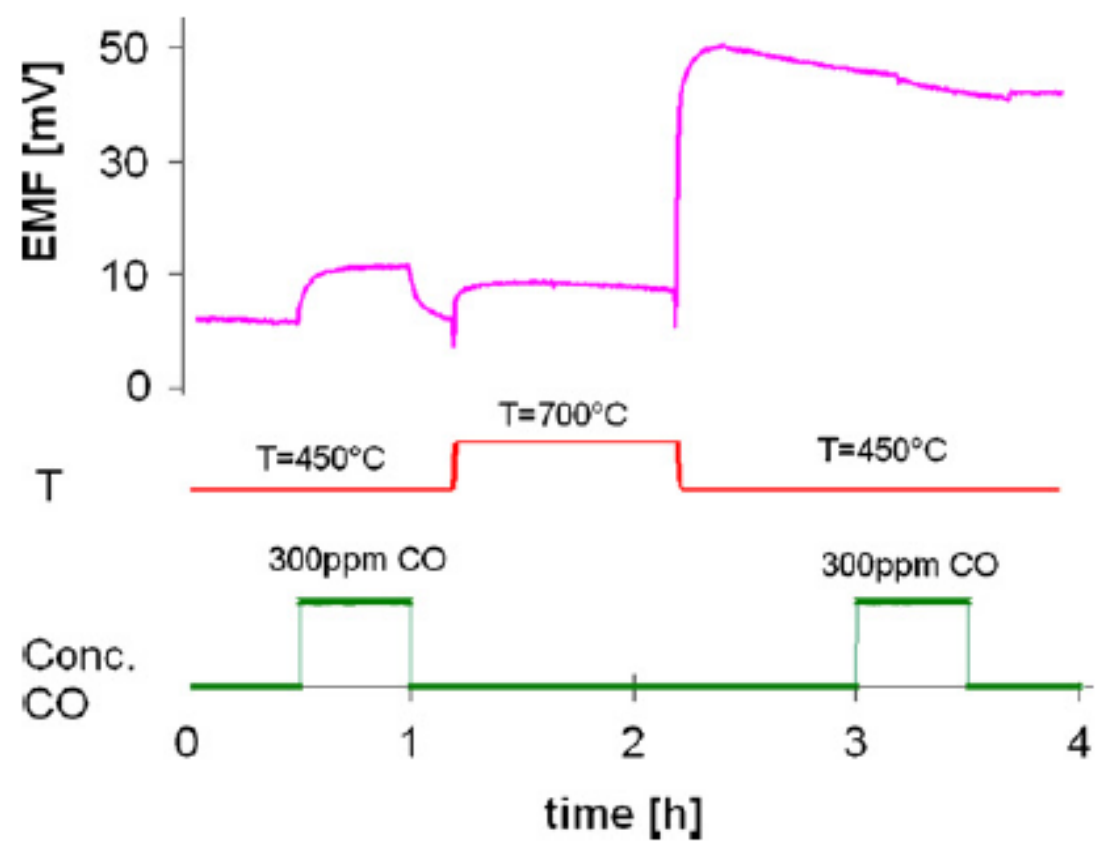

Figure 7: Regeneration process of the catalytic layer (Pt1.7 =1.7\% Pt dispersed in alumina) in the presence of 12 vol. $\% \mathrm{O}_{2}, 2$ vol. $\% \mathrm{H}_{2} \mathrm{O}$ and $\mathrm{N}_{2}$ balance.

\section{III.5. Adsorption and desorption behaviour of the catalyst}

In order to gain further knowledge of the deactivation/regeneration behaviour, temperatureprogram desorption (TPD) experiments have been carried out on the same Pt1.7 powder which was used for the elaboration of the catalytic filter. Before the TPD experiments, the powdered catalyst was calcinated in air at $850^{\circ} \mathrm{C}$ for $1 \mathrm{~h}$ in order to simulate the deposition procedure of the filter. Figure 8 shows the NO (30 amu) and oxygen (32 amu) desorption profiles in helium after a pre-treatment of the catalyst in $300 \mathrm{ppm} \mathrm{NO}_{2} / 3.5 \% \mathrm{O}_{2}$ atmosphere for $12 \mathrm{~h}$ at $450{ }^{\circ} \mathrm{C}$, the temperature at which deterioration of the sensing responses was observed.

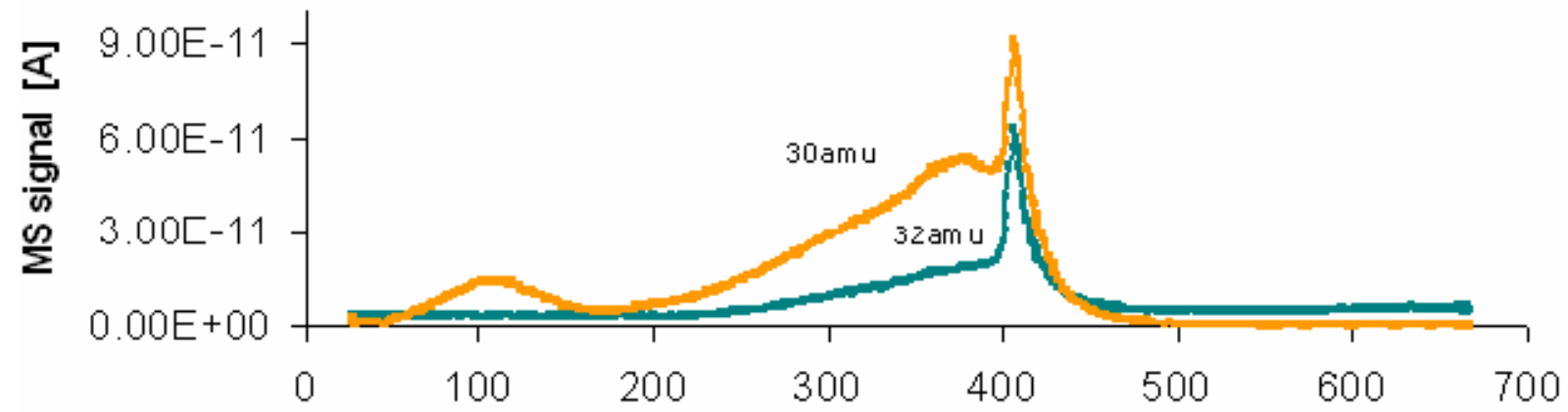

Figure 8: TPD in helium of a 1.7\% Pt dispersed in alumina catalyst after a pre-treatment of $12 \mathrm{~h}$ in $300 \mathrm{ppm} \mathrm{NO}$, $3.5 \% \mathrm{O}_{2}$ and He balance at $450{ }^{\circ} \mathrm{C}$.

TPD spectrum of NO desorption exhibits two peaks. The first peak centred at $100{ }^{\circ} \mathrm{C}$ is believed to represent NO chemisorbed on platinum as reported in the literature [21]. The peak integration gives a value of $11 \mu \mathrm{mol}$ of NO adsorbed on Pt per gram of catalyst. Considering one Pt atom for one NO molecule, the Pt dispersion can be estimated to be $12.6 \%$. As the desorption of these species is already completed at around $150^{\circ} \mathrm{C}$, it seems to be justified to presume that it will not affect the sensor function at $450^{\circ} \mathrm{C}$. 
The second desorption peak starts at approximately $200{ }^{\circ} \mathrm{C}$ and continues up to $460{ }^{\circ} \mathrm{C}$. The amount of $\mathrm{NO}$ desorbed is calculated to be $88 \mu \mathrm{mol} / \mathrm{g}$. As oxygen desorption (at $32 \mathrm{amu}$ ) takes place at the same time, this peak is believed to belong to decomposition of nitrates or nitrites adsorbed on the alumina support [22] which generates simultaneous desorption of NO an $\mathrm{O}_{2}$. It should be noted here that the concentration of desorbed nitrates and nitrites corresponds to the overall amount of $\mathrm{Pt}(87 \mu \mathrm{mol} / \mathrm{g})$. This suggests that these species could be formed on or around the Pt particles, thus decreasing their catalytic properties.

These results correspond well with the experimental observations of the sensor. At temperatures lower than $500{ }^{\circ} \mathrm{C}$, nitrates and nitrites are not decomposed, which causes deactivation of the catalytic layer. This explains deterioration of the sensor responses observed at $450^{\circ} \mathrm{C}$. At higher operating temperatures, desorption of nitrates and nitrites takes place. This process regenerates the catalytic properties of the filter. Moreover, if the working temperature above $500{ }^{\circ} \mathrm{C}$ is maintained, no deactivation is observed.

\section{III.6. Interference of hydrocarbons}

Hydrocarbons (HC) are apart from $\mathrm{CO}$ the most important interference species for $\mathrm{NO}_{\mathrm{x}}$ sensors in car exhaust. Therefore it is absolutely necessary to suppress the sensor response to these gaseous species by oxidizing them to $\mathrm{CO}_{2}$ and $\mathrm{H}_{2} \mathrm{O}$. In a catalytic flow experiment it was determined that $125 \mathrm{mg}$ of the Pt1.7 catalyst, calcinated $1 \mathrm{~h}$ at $850^{\circ}$, can fully oxidize $500 \mathrm{ppm}$ propane and/or propene from $400{ }^{\circ} \mathrm{C}$. However, as expected, a full conversion of methane was not reached below $500{ }^{\circ} \mathrm{C}$.

Figure 9 shows the response of two sensors with different contents of platinum dispersed on the catalytic filter. The sensors were exposed at $450^{\circ} \mathrm{C}$ and $500{ }^{\circ} \mathrm{C}$ to a hydrocarbon mixture (25\% methane, $25 \%$ butane and $50 \%$ propene) in $12 \%$ oxygen. As expected, in the absence of a catalytic filter, the sensor responses to the hydrocarbon mixture are important in the order of $10-50 \mathrm{mV}$ as observed in the presence of $\mathrm{CO}$. These interferences are attenuated by adding a catalytic filter of the type Pt1.7. However, the sensor responses are not completely removed suggesting that the filter layer has not been able to fully oxidize $50 \mathrm{ppm}$ of the HC mixture even at $500{ }^{\circ} \mathrm{C}$. Though, when the percentage of platinum was raised in the catalytic layer up to $4.5 \mathrm{wt} . \%$ the sensor responses to the $\mathrm{HC}$ mixture are very weak at $450^{\circ} \mathrm{C}$ and completely suppressed at $500{ }^{\circ} \mathrm{C}$.

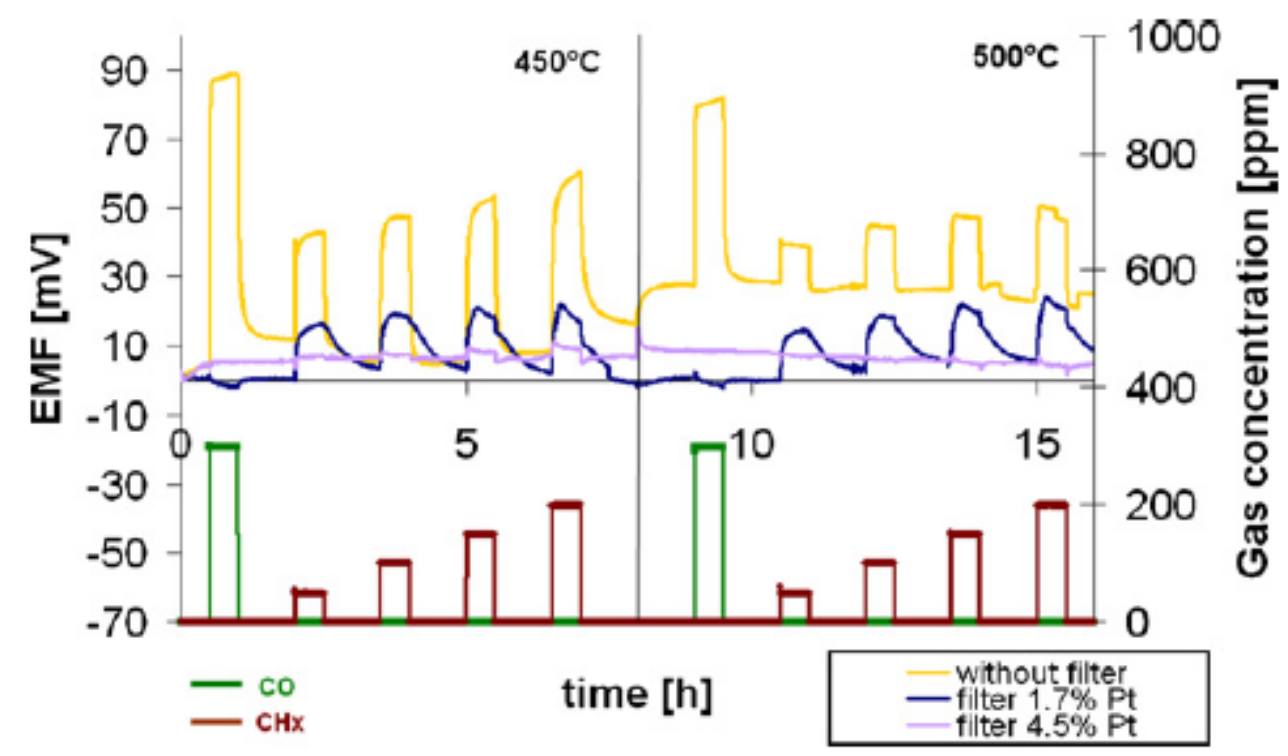

Figure 9: Sensor response to hydrocarbons ( $\mathrm{HC}=25 \%$ methane, $25 \%$ butane and $50 \%$ propene) at $450{ }^{\circ} \mathrm{C}$ and $500{ }^{\circ} \mathrm{C}$, respectively, in the presence of $12 \mathrm{vol} . \% \mathrm{O}_{2}, 2 \mathrm{vol} . \% \mathrm{H}_{2} \mathrm{O}$ and $\mathrm{N}_{2}$ balance.

As mentioned in Section I, the idea of reducing interferences by using a catalyst is well discussed in the literature [18], [19] and [23], zeolite filters such as NaY or PtY seem to be among the most successful ones in the application [24] and [13]. The choice using Pt on 
alumina support is driven by the easy preparation process and high reproducibility which are well suited for industrial fabrication.

\section{Conclusions}

A simple robust $\mathrm{Pt} / \mathrm{YSZ} / \mathrm{Au} \mathrm{NO}_{\mathrm{x}}$ sensor is presented in this work. It is shown that by deposing a catalytic filter layer over the sensing elements, $\mathrm{CO}$ and light hydrocarbon interferences to the $\mathrm{NO}_{\mathrm{x}}$ signal can be totally cancelled, yielding to a higher $\mathrm{NO}_{\mathrm{x}}$ selectivity. By using TPD analysis an optimal working temperature can be found to avoid deactivation of the catalytic filter. It is shown that it is advisable to work at a temperature higher than $500{ }^{\circ} \mathrm{C}$ to force nitrates or nitrites decomposition. However once selectivity is achieved, an improvement in the sensitivity is necessary to grant industrial application. Therefore, lower temperatures may be necessary in order to achieve higher sensitivity of the signal. In that case, a calcination step of the sensor at $700{ }^{\circ} \mathrm{C}$ can be applied to regenerate the catalytic activity of the filter layer.

\section{References}

[1] Ono, M. Hasei, A. Kunimoto and N. Miura, Solid State Ionics 175 (1-4) (2004), pp. 503506

[2] X. Li, W. Xiong and G.M. Kale, Electrochemical Solid-State Letter 8 (2005), pp. H27H30.

[3] F. Menil, V. Coillard and C. Lucat, Sensors and Actuators B: Chemical 67 (2000), pp. 123.

[4] E. Billi, J.-P. Viricelle, L. Montanaro and C. Pijolat, IEEE Sensors Journal 2 (2002).

[5] J.W. Fergus, Sensors and Actuators B: Chemical 122 (2007), pp. 683-693.

[6] P.T. Moseley, Solid state gas sensors, Measurement Science Technology 8 (1997), pp. 223-237.

[7] U. Guth and J. Zosel, Ionics 10 (2004), pp. 366-377.

[8] N. Guillet, R. Lalauze and C. Pijolat, Sensors and Actuators B: Chemical 98 (2004), pp. 130-139.

[9] C. Pupier, C. Pijolat, J.C. Marchand and R. Lalauze, Journal of Electrochemical Society 146 (1999), pp. 2360-2364.

[10] E.L. Brosha, R. Mukundan, R. Lujan and F.H. Garzon, Sensors and Actuators B: Chemical 119 (2006), pp. 398-408.

[11] P. Viricelle, A. Pauly, L. Mazet, J. Brunet, M. Bouvet, C. Varenne and C. Pijolat, Materials Science and Engineering: C 26 (2-3) (2006), pp. 186-195.

[12] J.C. Yang and P.K. Dutta, Sensors and Actuators B: Chemical 123 (2007), pp. 929-936.

[13] N.F. Szabo and P.K. Dutta, Sensors and Actuators B: Chemical 88 (2003), pp. 168-177.

[14] S. Zhuiykov and N. Miura, Sensors and Actuators B: Chemical 121 (2007), pp. 639-651.

[15] Xiong and G.M. Kale, Sensors and Actuators B: Chemical 114 (2006), pp. 101-108.

[16] N. Miura, M. Nakatou and S. Zhuiykov, Ceramics International 30 (2004), pp. 11351139.

[17] J.W. Fergus, Sensors and Actuators B: Chemical (2007), pp. 652-663.

[18] M. Ono, K. Shimanoe, N. Miura and N. Yamazoe, Solid State Ionics 136/137 (2000), pp. $583-588$.

[19] S. Kitsukawa, H. Nakagawa, K. Fukuda, S. Asakura, S. Takahashi and T. Shigemori, Sensors and Actuators B: Chemical 65 (2000), p. 121.

[20] A. Morata, J.P. Viricelle, A. Tarancon, G. Dezanneau, C. Pijolat, F. Peiro and J.R. Morante, Sensors and Actuators B: Chemical 130 (2008), pp. 561-566.

[21] S. Benard, L. Retailleau, F. Gaillard, P. Vernoux and A. Giroir-Fendler, Applied Catalysis B: Environmental 55 (2005), pp. 11-21.

[22] R. Burch, J.A. Sullivan and T.C. Watling, Catalysis Today 42 (1998), p. 1.

[23] K. Sahner, G. Hagen, D. Schönauer, S. Reiss and R. Moos, Solid State Ionics 179 (2008), pp. 2416-2423.

[24] N.F. Szabo, H. Du, S.A. Akbar, A. Soliman and P. Dutta, Sensors and Actuators B: Chemical 82 (2002), pp. 142-149. 